\title{
Subud: An Indonesian Interpretation of Ṣūfism
}

\author{
Antoon Geels
}

$1 \quad$ Introduction

Subud is one of hundreds of mystical movements (aliran kebatinan) that have grown significantly in post-war Indonesia. Along with other movements like Sumarah and Pangestu, Subud has attracted people from the West and has now spread to 83 countries, divided into nine zones. The total number of members is estimated at close to twelve thousand. Despite the fact that Subud leaders deny any relation to the Javanese mystical tradition, it can easily be shown that the greater part of Subud's conceptual apparatus is firmly rooted in the cultural history of Java. Under the banner of change and renewal, Subud presents a message that, fundamentally, is one of continuity in a society in transition. Subud's ideas and practices underline not only the variety within Islamic sects and movements, but also the adaptability to local traditions, as the present chapter will try to show.

Subud is an acronym for Susila Budhi Dharma, words of Sanskrit origin. According to Muhammad Subuh Sumohadiwidjojo, the founder of Subud, the meaning of these three words is "to follow the will of God with the help of the Divine Power that works both within and without, by way of surrendering oneself to the will of Almighty God." As such Subud "may be attached to the whole of mankind in every religion." This means that Subud also can be presented as an example of 'glocal' spirituality. Subud attaches to local spiritual traditions, including Hinduism, while simultaneously having the ambition to reach out globally. The focus in this chapter will be on a short biographical presentation of the founder, the basic concepts of Subud, its specific spiritual exercise (latihan kejiwaan), and, finally, the Javanese background of Subud, especially focused on the nineteenth century renaissance period and the rise of mystical movements in post-war Java.

\section{The Life of Muhammad Subuh Sumohadiwidjojo (1901-1987)}

Raden Mas Muhammad Subuh Sumohadiwidjojo, the founder of Subud, usually called Bapak (a conventional honorific term, meaning 'father'; here referred 
to as Subuh), was born on 22 June 1901, in a small village near Semarang, the capital of the province Central Java. The name Muhammad does not necessarily mean that Subuh was an orthodox Muslim (santri), but like millions of other Indonesians Muhammad Subuh would regard himself as a Muslim though he did not observe all five pillars of Islam. He did not perform regular Friday prayers at the mosque, and despite extensive travelling around the world, the founder of Subud did not make the pilgrimage to Mecca (Sitompul 1974: 61-62).

Although Muhammad Subuh always claimed to be an 'ordinary' person, his life, as told by himself, provides proof that he was a remarkable man. At his birth volcanoes erupted, as is common in Javanese folklore when an important person is born. At the age of six or seven Subuh went to a private Dutch school. The young Subuh turned out to be a very sensitive boy. He did not like to see boys fighting and was unable to read degrading or false information about Indonesia in Dutch schoolbooks. He also displayed a clairvoyant faculty and was teased for it by other children, who did not like the fact that Subuh could clearly see things that they could not see in the ordinary world. It is also important to note that the family of Subuh held in high esteem traditional Javanese values, like the practice of self-denial, values that Subuh retained all his life (Longcroft 1993: Chapter 4).

When Subuh was fifteen or sixteen years old he had a decisive experience. One night an old man, dressed in black and carrying a staff, awakened him. Later Subuh understood that this man must have been Sunan Kalijaga, an ancestor saint who returned to this world in order to look after Subuh when he could not take care of himself (Sumohadiwidjojo 1991: 23-24). The man approached the astonished boy and uttered this prophecy: "Remember. When you are thirty-two years old, you will be called by Almighty God." For Subuh this could only have one single meaning: he was going to die at thirty-two (Longcroft 1993: 30). Muhammad Subuh mentions that this experience came to him shortly after he received the message that his grandfather had died. "I was very shocked by the news," he writes many years later in his autobiography, and adds that he no longer had the will to study and rather wanted to start work.

In the years to come Subuh became the breadwinner for his family. He worked as a bookkeeper at the Semarang City Hall. During these years he also felt an intense spiritual quest related to the prophecy he had received some years earlier. If he was going to die at thirty-two, he surmised, it was better to search for higher values. His spiritual journey took him to a number of teachers. The most important spiritual teacher of Subuh during these years was Shaykh Abdurachman. He was also the last one to whom Subuh went to receive 
spiritual guidance. Abdurachman was a well-known shaykh of the Naqshbandī order of dervishes. Like most other spiritual teachers he immediately noticed 'the spiritual potential' of the young Muhammad Subuh (Longcroft 1993: 46).

Muhammad Subuh received the latihan kejiwaan, the spiritual exercise of Subud, in 1925 when he was twenty-four years of age. This unexpected experience concluded his search for spiritual teachers. As he tells the story, one night, around midnight, after hours of studies, Subuh put his books aside and went for a walk. Suddenly, and surprisingly, he noticed "a light shining from above a ball of radiant white light," falling onto his head. Then it happened:

My body started shaking; my chest was heaving. I feared I would collapse in the street. I quickened my pace to get home as quickly as possible. But on reaching the house, the shaking stopped and my chest was calm. I knocked on the door, which was immediately opened by my mother, who asked, 'Why do you look so pale?' to which I responded, briefly, 'It's nothing!'

I went directly to my room and stretched out on my bed. I folded my arms over my chest and surrendered to Almighty God. Amazing: I saw my whole being filled with light. This lasted for just half a minute. Then I arose, but not from my own will, and went to the room that I used for prayer and study. There I stood and performed two raka'ats of prayer. After finishing the prayer, I returned and lay down again on my bed and fell asleep.

SUMOHADIWIDJOJO 1990a: 24

This was Muhammad Subuh's first experience of the Subud latihan, characterised by a total surrender to Almighty God. In Subuh's biography it is added that he was reminded of the words uttered by the old man in black, who prophesied that God would call him, interpreted by Subuh that he would die young. If this was the time, then he should surrender completely, which is why Subuh lay down on his bed with his arms crossed on his chest (Longcroft 1993: 49).

Subuh felt troubled by this kind of experience. At that time, he did not really understand its deeper meaning. Apparently, Sheikh Abdurachman could not explain them either. A number of similar experiences came to him shortly afterwards. Only a few months later, when performing the dhikr ritual, reciting the prayer là iläha illa 'llāh, ("There is no god but God"), spontaneously during latihan, he saw and felt a large book falling into his lap. On the first page he saw the picture of an Arab in a long robe and wearing a turban. Subuh tried to read the Arabic script, which suddenly changed into Roman characters and in 
Dutch translation. He read: "The Prophet Muhammad Rasulu'llah." Strangely enough the picture smiled and nodded, confirming the interpretation. Then Subuh turned the page and saw Javanese people; on other pages there were people representing many different races. All of them were moving, praying, crying, shouting, and asking God for forgiveness. Then the book vanished into his chest (Longcroft 1993: 52ff; see also Sumohadiwidjojo 199oa: 29-30).

During this period Subuh met his future wife, Rara Ruminda. They married in October 1926. Ruminda gave birth to four children. Siti Rahayu was born in 1928, followed by Haryono two years later, and eighteen months later by Haryadi. Their youngest child, Siti Hardiyati, was born in 1935 .

The first group around Subuh was formed among the followers of Shaykh Abdurachman. Subuh still considered himself to belong to that group. Soon a small group of Abdurachman's pupils started to visit Subuh's house regularly. In 1932-33 some of these friends received the latihan. Slowly, the latihan spread to a group in Semarang and elsewhere in Java.

During these years Subuh had his most important spiritual experience, referred to as his ascension. According to his biographer it is most likely that this experience came to Subuh in the middle of 1933, around the time that he decided to give up his worldly work. This must have been a worrying time for his wife Ruminda, who at the time was only twenty-one years of age. After all, Subuh was the main financial provider for her and her small children, as well as for other members of his family.

No doubt, this must have been a confusing time for Subuh as well. One evening, when at home, he felt his body growing weak, his mind emptied. Suddenly he was aware of the prophecy of the old man in black, who told the schoolboy Subuh that at thirty-two years of age he would be called by Almighty God. Subuh stretched out on his bed and "surrendering to the Power of Almighty God" he suddenly felt his body "lengthen, widen and expand" and he moved at great speed across "a huge expanse." In his own words:

Before me I could see mountain-like cones of light, seven of them, stacked one above the other, and each connected by a cord of brilliant white light. I approached the first cone and entered it. Within could be seen a vast panorama, much greater than that I had seen before.

There I saw Almighty God's creatures clad in white and praising the majesty and greatness of Almighty God ... It seems I was not permitted to stay too long as I was transported again and found myself entering the second mountain from below, then I went up until I reached the sixth mountain where I felt completely powerless. 
In this state of utter weakness I felt myself saying, 'Allahu Akbar, Allahu Akbar, Allahu Akbar.' Only then did I enter the seventh cone. There I had no direction and no purpose other than to say, 'Allah, Allah, Allah.' But from there I could see anything and everything that was very distant, including the world that I had left.

SUMOHADIWIDJOJO 1990a: 34-35

It was only after his ascension that Subuh started to 'open' other people, that is, initiate them into the Subud latihan. Slowly the latihan began to spread, first in Java and then, more than two decades later, all over the world (Longcroft 1993: 67ff).

While Subuh and his family were still living in Semarang, a small group in Yogyakarta, 'opened' and guided by Subuh, started an organisation called Ilmu Kasunyatan (ilmu means 'esoteric spiritual knowledge'; kasunyatan means 'emptiness') (Longcroft 1993: 73-74). During the next twelve years after the ascension Subuh and his family lived a life of hardship. He had no work and was financially dependent on others for support. When their sixteen-month-old boy Suharyo died in August 1934, young Ruminda became severely depressed. In 1936 she fell ill and passed away.

In November 1941 Subuh remarried to Ibu Siti Sumari who was thirty-four years old and the mother of two children. This second marriage was of tremendous importance for Subud. Ibu Sumari made the Subud latihan available for women. In his autobiography Subuh writes: "My family life was complete again. We lived simply but always felt at peace and calm, so I was able to be diligent in the latihan kejiwaan that I had received through the grace of Almighty God" (Sumohadiwidjojo 1990a: 32; see also Longcroft 1993: 95ff).

Like many other families they lived through a time of hardship during World War II and the Japanese occupation of the Dutch East Indies. The Dutch surrendered the country to the Japanese in March 1942. Subuh tried to survive by starting a small contracting business together with eight other persons. After the war, in February 1946, Subuh and his family moved to Yogyakarta.

Towards the end of 1946 membership increased from about twenty to two or three hundred. A few months later, on 1 February 1947, journalists, government officials, and others were invited to an inaugural meeting in a reception room at the City Hall of Yogyakarta. On that occasion Subuh proclaimed the name chosen for the new organisation: Subud, an acronym for Susila Budhi Dharma.

The words 'Susila Budhi Dharma' are of Sanskrit origin. According to the interpretation of Subuh, susila means 'to be able to live according to the will of God as really true human beings'. Budhi, usually translated as 'endeavour', 'power of the intellect', or 'consciousness' in the Indonesian vocabulary, refers 
to a divine power within man and all creation, according to Subuh. Dharma, usually translated as 'religion', 'righteousness', or 'duty', is translated by Subuh as "the possibility for every creature, including man, to surrender completely to the will of God" (quoted in Sitompul 1974: 80). The combination of the three words thus means "to follow the will of God with the help of the Divine Power that works both within and without, by way of surrendering oneself to the will of Almighty God" (Sitompul 1974: 80). As such Subud "may be attached to the whole of mankind in every religion" (Sumohadiwidjojo 1984b [1961]: 245; Longcroft 1993: 121).

In his speech to the invited people Subuh emphasised that Subud "had no holy book, no teaching, no sacred formulas, no methods of meditation ... In Subud the members only surrender with patience, trust, and sincerity to Almighty God." In addition to all this Subuh also explained that Subud is not a political party and that its members will obey the laws of the state (Longcroft 1993: 122-123).

After independence on 17 August 1945 membership was rapidly increasing. In May 1957 Subuh and his wife Ibu left Jakarta for England. There they met important people, including Dr John G. Bennett a leading follower of the mystic G.I. Gurdjieff, who had died some years earlier. The followers of Gurdjieff, about 1200 in number, were looking for a new master. When Muhammad Subuh came to England, invited by Bennett and his Gurdjieff group, he was welcomed by a great number of people.

Since 1959 Subud has arranged World Conferences, held every fourth year. Muhammad Subuh became known to the world of Subud as Bapak or 'father'. In 1970 the American scholar Jacob Needleman, in his book The New Religions, could write that Subud is the most widespread of all the new teachings, being spread in more than sixty countries throughout the world (Needleman 1970: 104). Today this number has increased to 83 countries. After 1955 the Headquarters of Subud moved to Jakarta. In the early 196os Subuh managed to buy some land on the outskirts of the capital. In time it became known as Wisma Subud, situated in a village called Cilandak, and Subud members from overseas donated considerable sums of money for construction projects.

\section{Basic Concepts in Subud}

\subsubsection{God and Creation}

Although the idea of God is implicitly included in Subuh's talks, there are relatively few lengthy statements about God. The simple reason for this is that God cannot be known by the human mind. Like other mystics Subuh sometimes 
uses negative descriptions of God. Allāh, he says, "has no form, no colour, no time, no place, no nationality, no country" (Sumohadiwidjojo 1967: 80). "Do not try to understand the impossible," Subuh exhorts his followers. But in order to be able to communicate about God, Subuh usually refers to "the Great[est] Life" (hidup yang maha besar) (Sumohadiwidjojo 199oc [1957]: 119). This Great Life permeates the whole universe; it is "within all that is within, and outside all that is outside, and God goes before all that is before and comes after all that is after" (Sumohadiwidjojo 1993: 113; 1988a: 18).

This concept is similar to the most basic idea of God in mystical theology: a combination of immanence and transcendence. In relation to man, God is near and simultaneously far away, Subuh says, reminding us of a few words from the Qur'ān, often quoted by the Șüfis: "God is nearer to you than your jugular vein" (Sura 5o:16). "The power of God is within man," says Subuh: "God is closer to a human being than if he sees with his own eyes, God is closer to a human being than when he thinks his own thoughts. God is closer to a human being than when he feels his own feelings" (Sumohadiwidjojo: 1993: 84). "But if a man wishes to go toward God," he also says, "then, o dear, He is far, far away; that is to say, the distance cannot be measured" (Sumohadiwidjojo 1969: 112). Despite the utter unknowability of God for the human mind, it is possible for man to be guided by His power, which is within every human being. "God is within you, God is there all the time, God accompanies you in everything that you do" (Sumohadiwidjojo 1988a: 5; 1981: 11). "Your inner self ... keeps you constantly in touch with the Great Life" (Sumohadiwidjojo 1993: 17).

Although most references to God are of an abstract kind, like in epithets such as "the Great Life" or "the Life Force," being "the light and the guide within the individuality of each of you" (Sumohadiwidjojo 1984b:153), Subuh occasionally uses personal terms like "the One who watches over you" (Sumohadiwidjojo 1990c: 183). Expressions such as the aforementioned are certainly of a second order in relation to abstract references to God. Sometimes Subuh says that it does not matter how we designate God. God is Almighty, All-Powerful, and All-Knowing. It is impossible for man to picture God, because God has no form. But man can reach a certain understanding of God since he has been given the capacity of understanding. Being immanent in His creation God encompasses the whole universe. Nothing is lifeless, as modern physics has proven (Sumohadiwidjojo 1989: 12-13).

Subuh does not talk often about creation. In the beginning there was emptiness, silence, and the first vibration (qadr ilham, sometimes spelled as hadir ilham) that issues from the will of God (Sumohadiwidjojo 199ob: 13). "Such utter isolation," Subuh says in a talk from 1982, "is referred to in Javanese as samun suwung, a total void." Then, he continues, 
there arose for the first time the so-called nur ghaib, the light of Life, the source of everything, and its vibration and radiance, as it spread everywhere, created the light and heat of the sun, fire, air, water and earth. It is said that with the creation of these four elements there also arose the forms of life, starting from the material, to the vegetable, the animal, the human and others beyond. All these arose spontaneously, growing together. Such is the story of life as received by the prophets and the messengers of God.

SUMOHADIWIDJOJO 1983b: 18-19

So, in the beginning there was emptiness and vibration, the same basic vibration that can be felt in the Subud spiritual exercise, the life within a life. Then there was light, which explains why important messengers like Jesus are always depicted as surrounded with light or with a halo, "as if his body is bathed in light that comes down from above" (Sumohadiwidjojo 199ob: 13). After the manifestation of light, the four elements were created, and the four basic forms of life.

Subuh, through his compiler, describes creation as an emanation process: God "decided to test His Own Power" by making "something out of nothing" (quoted in McKingley 1992: 1). The world as we know it is materialised spirituality, passing through the four elements, successively condensed into gross matter. The first human beings were Adam and Eve, existing first in a state of original unity when there was just light. This was a state of perfection, a state of bliss. Everything needed was provided for, just like the unborn baby in the mother's womb. God created a physical body for Adam, a body with senses, a heart and mind, and he gave it all kinds of forces, intended to be useful in this world: vegetable, animal, human, and 'other forces'. Equipped with all this, Adam was able to live in the world and although he was sad to leave his state of original unity, he soon adopted to this new world, forgetting about eternal bliss. But by giving Adam the Holy spirit (Roh Ilofi) and the power of the angels (Roh Kudus) God made it possible for Adam and his children to remember the state of original unity. To take us back to this state is the most profound task of the latihan kejiwaan (McKingley 1992: $3 \mathrm{ff}$ ). This means that we have to study another two aspects of the Subud doctrine: the view of man and the essence of the spiritual exercise.

\subsection{The Concept of Humanity}

It is obvious from Subuh's explanation of the biblical story of Adam and Eve that they and their descendants are equipped with all kinds of forces, powers, and capacities that enable man both to live in the world and to transcend it. 
We will now go deeper into the human and divine capacities of humankind. This brings us to the following doctrines: the seven universal life forces; the four types of nafsu (will, desire); the four bodies of man; and the concept of jiwa (soul).

Life as it really should be, Subuh says, "is a chain of being that is harmonious" (McKingley 1992: 44). The concept of 'harmony', often used by Subuh, is important and used in different contexts. Here it primarily means altruism, to live and show respect to fellow human beings, independent of race or nationality (Sumohadiwidjojo 1988a: 2, 1979: 26). Mankind is truly one, "and if this can become general then it is the way whereby the world can achieve a state of peace, a state of harmony, and can become different from what it is today." This state of being, Subuh adds, is an ideal and realised only by the few (Sumohadiwidjojo 1989:3-4).

The most ordinary state of being is not harmonious. Humans are constantly being influenced by lower forces, originating not only from oneself, but also from one's parents and generations of ancestors (Sumohadiwidjojo 1969: 104). These lower forces are four in number. The lowest is the material or satanic force (daya rewani) (Sumohadiwidjojo 199oc: 135). The next level is the vegetable force (daya nabati), more powerful in influence. Like the material force, and the other lower forces, the essence of the vegetable force is already present in the human body. There is a mutual influence between plants and other lower forces and human beings.

As well as rice and vegetables people also eat meat. We now reach the third lower force, the animal force (daya hewani), even stronger in influencing the feelings of humans and thereby impeding progress (Sumohadiwidjojo 199ob: $247 \mathrm{ff}$ ). The fourth of the lower forces are related to the ordinary human being (daya jasmani) and acts in sexual union. It is an even "mightier" influence (Sumohadiwidjojo 199ob: 263ff). These four forces should be our inner servants, not our masters.

In addition to the lower forces there are three higher forces. The roh rohani is the finer human soul (McKingley 1992: 10). Subuh also refers to this level with the expression "the force of the true human being" (daya insani) (Sumohadiwidjojo 1993: 33-34). Being above the ordinary human level, the higher forces are difficult to describe. Subuh says that there is a dividing line between the lower forces, the realm of the nafsu, and the three higher levels (Sumohadiwidjojo 1985: 51). The true human being is free from self-interest (Sumohadiwidjojo 1969: 67); "the perfect human soul ... goes straight to God and worships Him" (Sumohadiwidjojo 1984b: 66). Beyond this level Subuh mentions the rahmani and rabbani levels (Sumohadiwidjojo 1969: 9o). 
The presentation and discussion of the seven forces, especially the lower four of them, is a favourite theme in Subuh's talks. Another frequent topic is the struggle with the different desires or passions of man. We touch upon the important concept of nafsu, usually translated as passion, of which there are four. The first one is called nafsu amarah, red in colour. It is connected with will, desire, and anger. This nafsu is also closely related to the material life force, which we cannot get rid of. The reason for this is that man "while in this world, is composed of the elements earth, water, air and fire," the four material elements (Sumohadiwidjojo 1973: 161).

The second type is called the nafsu aluamah, black in nature and colour. Its characteristic is greed, and it is related to the vegetable life force. "Trees and plants provide food. By nature they are competitive, greedy" (Sumohadiwidjojo 1973:163). This nafsu is an obstacle to the worship of God. Then comes the nafsu Süfyah or supiyah, yellow in colour, the colour of spirituality. It has to do with attraction between men and women, and it is related to the animal life-force. It is needed in order to develop "the passion of love and unite with the opposite sex." When this has been achieved, the nafsu appropriate to man, connected to the human life force, can be developed. This is the nafsu mutmainah, white in colour. This nafsu "is an especially good one, a holy one. It is the nafsu of the human level" (Sumohadiwidjojo 1965: 165). Thus, the relation between the different nafsu and the lower forces is that they are usually intermingled, causing a negative or positive spiritual development.

A third important doctrine, necessary for a proper understanding of the Subud view on spiritual development, is the teaching about the four bodies of man. In one of his early talks, Subuh uses a diagram consisting of four circles. The outer one is man's physical body; the second circle represents the body of feeling and emotions; the third circle is the body of understanding, while the last one represents "inner peace or the consciousness of the inner feeling" (rasa diri) (Sumohadiwidjojo 1993: 12ff).

We cannot leave the Subud view of man without touching upon the concept of jiwa, one of the Hindu influences on Subuh's thoughts. In the earliest published book of Subuh, a book which is not composed of talks, but consists of a systematic survey of his ideas, it is stated that man should not neglect "training in the realm of the jiwa." In its context, this statement obviously means spiritual development. Through the influence of the lower forces and the nafsu, people can lose their human jiwa. That is why they need to develop "the inner nature of mankind - the kejiwaan" (Sumohadiwidjojo 199ob: 221). This means that the concept of jiwa is related to different levels of spiritual development. In his Cilandak talks Subuh explains about this developmental aspect when 
commenting upon the concept of kejiwaan (Sumohadiwidjojo 1973: $36-37$, see also 1983a: 4):

The kejiwaan, however, does not depend on the power of thought, but rather on the glory, the greatness of God, Whose Power envelops all, from the jiwa of matter to the jiwa Rabani (Spirit of the Almighty), to the jiwa Ilofi (the Great Life Force) and up to the jiwa Roh Kudus (the Holy Spirit).

Thus, the jiwa is spiritual, it is the sum total of human capacities and possibilities, entangling the whole hierarchy of the physico-spiritual universe. In the same talk Subuh describes the jiwa as an atmosphere: "The jiwa is an atmosphere surrounding you, enveloping you, just as you are enveloped by bright light when you stand in the sunshine at midday, or by darkness in the middle of the night when there is no sun" (Sumohadiwidjojo 1973: 35). In this atmosphere there is a dimension that is eternal. "The jiwa God gives can never be destroyed" (McKingley 1992: 7).

\subsection{The Return to Original Unity}

In Subud, the world is materialised spirit, reaching an ever-increasing level of density. The whole of creation aspires to return to the original state of unity, symbolised by the story of Adam and Eve. The universal pulse consists of a double movement: emanation and ascension. Although we live in a world of multiplicity, there is unity in plurality; the Great Life Force is eternally immanent in its creation. It is the privilege of man to 'taste' this unity, to be in touch with the Omnipresent, supporting Life Force.

In the following quotation from the texts of Subuh we encounter this fundamental idea, so common in the mystical theology of world religion, in Arabic Șūfi terminology:

[E]verything originates from God. This cannot be denied; no. Inna illahi wa inna ilaihi rojiun (from God we come and to God we return). It is not only words when we say that we come from God and return to God. No. Everything is from God, and everything will return again into the power of God. No more and no less.

SUMOHADIWIDJOJO 1981: 18

Subud emphasises personal, non-mediated experience of God's presence. But due to the influence of the lower forces, the nafsu, and the four bodies of man, the more common situation of man is at best to be aware of God's absence. The longing for divine presence and guidance is the first step on a long and arduous 
road, described by Subuh in different ways. It is absolutely necessary, however, to undertake this journey with a pack containing some indispensable tools: to be able to surrender, to have patience (sabar), to trust in God (tawakal), to display an attitude of submission, and to be sincere (ikhlas). In addition to these fundamental capacities, Subuh also mentions the importance of losing self-interest and of being quiet: "You can yet come to understand all that is necessary just by being patient and quiet" (Sumohadiwidjojo 1990c: 183).

One of the most important concepts is surrender. In connection with the spiritual exercise (latihan kejiwaan) Subuh has already indicated what this means. We have to surrender everything in our feeling and thinking:

If you let go of all your thoughts, and let go of all that you feel in your inner feeling, and you really believe in God ... If, in the training [latihan], you think of something, even a little, it stops. Clearly, the training you receive - that is, your receiving in the training - cannot be mixed with your desires and thoughts.

SUMOHADIWIDJOJO 1993: 101

Before going deeper into the spiritual exercise and elaborating on its requirements, it is necessary to present the different stages in spiritual development, according to Subuh. Occasionally, Subuh refers to the four traditional stages within mystical Islam or Șūism. In a talk from 1959 he criticises other interpretations of the spiritual life for consisting of words only, a theoretical approach existing in the mind. All these approaches can be grouped under the headline tarikat, spiritual ways. But there are stages beyond tarikat (sometimes tarekat). Subuh divides all four of them in two groups:

The first two forms are called Shariat [Arab. sharīa, 'law'] and Tarikat [Arab. țariqa, 'path']. Shariat does not imply any search for the way to God, for all that is required is simply faith; that is to say, if a man already has faith in the counsel of those who have received in the past, it is held that such a faith will bring him straight to God, and that God will look after the faithful. The second form is Tarikat, which means the way to find the inner meaning of faith.

SUMOHADIWIDJOJO 1984b: 122-123

The first two stages are usually related to the religiosity of ordinary man. But deeper spiritual development can only be obtained when man reaches the second group of two stages: Hakekat [Arab. haqiqa 'truth'] and Makrifat (Arab. ma'rifa, 'knowledge'). The third stage can only be reached when all efforts 
have ceased: "This Hakekat only exists when a man comes to see that all his efforts are useless and that in truth this can only come to man by the Will of God." (Sumohadiwidjojo 1984b: 123). The meaning of Makrifat, Subuh explains, is "that a man has received the contact with and is filled by the Will of God, and is following that divine Will which exists within His being." The difference between the first and the final two stages is described in the following way:

Hakekat and Makrifat are qualities of a man who has received the contact with the Power of God to such an extent that he lives according to this power and becomes, in very truth, its instrument, whereas in the first two ways he is still the instrument of his own self-will; that is, of his thoughts, desires and feelings. This is the difference between Shariat and Tarekat on the one hand and Hakekat and Makrifat on the other.

SUMOHADIWIDJOJO 1984b: 123

Subuh adds that the two higher ways are received in the Subud latihan. In rare cases, spiritual development leads to the state of 'perfect man' (insan kamil), a person who has integrated all forces. Perfect man, Subuh says, "is equipped with the entire framework, the hierarchy of life-instruments or forces; and these exist within him to make his life in this world complete." Perfect man, Subuh continues, is not somebody who turns away from the world, somebody who isolates himself in a cave or in the jungle in order to meditate. Perfect man does not turn his back to society, he is socially-minded (Sumohadiwidjojo 1975: 67). A perfect human being or a perfect human soul (the soul called insani) "is one with the nature of a creature that knows the true life and knows, too, the life of other natures, and which always feels love, and loves and assists anyone in need, or those who are ill or in need of care" (Sumohadiwidjojo 1993: 44).

From what has been said above it is obvious that a purification process is needed in order to reach the state of perfect man. From an overall point of view the latihan kejiwaan is a purification process. This process proceeds at several levels of the psycho-physiological human being, starting with the body and our feelings. The purification process includes past sins committed by ancestors. Sometimes Subuh refers to the Hindu-Buddhist concept of karma. The influence from ancestors is firmly rooted in the Wayang stories (Rieu 1985: 26). In the words of Subuh: "inside the mistakes which you committed in your own life are the mistakes committed by your parents. And inside those mistakes are 
the mistakes of your grandparents" (Sumohadiwidjojo 1981a: 29; see also 1983b: 3, 1986: 2, 1993: 28).

It is obvious that the higher levels of latihan are just as rare as similar mystical states of consciousness in other traditions. In a booklet entitled This Is What I Have Been Hoping For Subuh mentions that during the twenty-five years that he first set foot in Europe only about fifty Subud members have received something "beyond their ordinary knowledge" (Sumohadiwidjojo 1983a: 12). The most important psychological prerequisites for reaching these higher levels can be summarised as letting go, that is, complete surrender to the will of God. A mystical way of expressing this important part of the exercise is to reach "death in life" (Mati sakjeroning urip) (Sumohadiwidjojo 1985: 36). The same idea is expressed in one of Subuh's New York talks:

Those men who received Grace in the days of old ... have repeatedly declared that in order to know and to realise the true, the real, life, which it is both necessary and possible for man to know, he is required to die before he really does die; that is to say, he should experience death before he really dies. This is symbolised in the death and resurrection of Jesus Christ, which represents the return of Life from death.

SUMOHADIWIDJOJO 1975: 12

The psychological description of this requirement is to "stop thinking and imagining" (Sumohadiwidjojo 199oc: 111). Subuh's advice to Subud members is to put aside all speculations, all thought. In a way it is like "re-entering the state ... as a small child free from the influence of the external world" (Sumohadiwidjojo 1984b: 28).

Subuh not only demands the inhibition of thought, but also "the cessation of your personal self" during latihan (Sumohadiwidjojo 1984a: 45). In addition to all this one should be free from desire: "If your thinking and desires interfere, your latihan stops by itself." In the next sentence Subuh says that it is necessary to surrender "body and soul to the One God" with trust, patience, and sincerity (Sumohadiwidjojo 1993: 67). The practice of latihan is not limited to the latihan hall, twice a week. Subuh advises experienced practitioners to do the latihan at home (Sumohadiwidjojo 1984a: 176). The experience of latihan is an on-going process leading, finally, to a permanent state in which Subuh claimed to be (Rieu 1985: 76).

From what has been mentioned above it is obvious that Subud is embedded in mysticism, in the sense of experiencing the immediate presence of God, leading to far-reaching consequences in the individual's life. One of the most common verbal expressions of this experience is to feel "a vibration of energy 
felt within the self," or "to make contact with the Great Life, or with the Power of God" (mendapatkan kontak dengan hidup-besar atau dengan kekuasaan Tuhan) (Sumohadiwidjojo 1990: 110-111).

What we receive in the latihan can be described as a vibration of life, called in Islam the hadir ilham. This vibration arises within our being the moment the nafsu ceases to act. Gradually it spreads to our whole body, eventually manifesting in the form of movements.

SUMOHADIWIDJOJO 1981a: 53

In one of his early talks in Coombe Springs, England, Subuh again mentioned that a person who has an immediate relation to the "Great Life" is called, in the language of Islam, a perfected human being (Sumohadiwidjojo 1993: 12; see also 1983 b: 58 ).

In summary, then, Subuh asks Subud members to stop thinking and desiring, to inhibit impressions from the external world, as well as to inhibit consciousness of the self. In short, to empty yourself: "When you are free from your thoughts, mind and desires in your exercises, and really become empty, only then will you be able to receive and be aware of blissful and light movements and other such actions within yourselves" (Sumohadiwidjojo 1975: 23).

With this last quotation we touch upon certain experiences that can be felt during latihan. Subuh mentions involuntary bodily movements, expressions of joy and sorrow, all coming from the soul (jiwa), not from the heart. Even if people only utter sounds like "Er, er, er, eh, eh, eh, ah, ah, ah" it is regarded as receiving, as coming "from the human soul ... and not from the other forces which suppress it" (Sumohadiwidjojo 1993: 77; see also 1988b: 9, 1979: 18ff). The latihan, Subuh explains, begins with "the coarse physical body, and later goes deeper to the inner feeling," cleansing as it goes. The result of this purification is that it brings to life "the real power of the soul or jiwa" (Sumohadiwidjojo 1993: 79).

The purpose of the latihan, then, is to purify the four bodies, that is, the physical body, the body of feelings and emotions, the body of understanding, and the inner feeling, as well as to calm the passions (nafsu). The necessary requirements are an attitude of "patience, faith, submission and sincerity towards the greatness of God" (Sumohadiwidjojo 1993: 56). Only then can we receive "guidance from the Great Life" during latihan (Sumohadiwidjojo 1993: 58).

From a societal point of view the latihan is beneficial for all mankind in our present, troublesome situation. One of the fruits of the latihan is "to bring our lives to a state of happiness and usefulness in this world" (Sumohadiwidjojo 
1986: 2; 1988a: 14). The latihan kejiwaan of Subud is a method or a way to reestablish original unity, a way of unifying all humankind, a method given to us through Muhammad Subuh, and adapted to the situation of humanity in the present age (Sumohadiwidjojo 1986: 21-22; 1989: 9).

\section{Subud as Javanese Mysticism}

As stated in the introduction, Subud leaders usually deny any relation to the Javanese mystical tradition. In this chapter, however, I have tried do show that the greater part of the conceptual apparatus of Subud is firmly rooted in Javanese mysticism. The latihan kejiwaan is the axis mundi of Subud. Due to this experiential basis of Subud, the concept of God and the view of creation receive a limited space in the talks of Subuh. God is described in terms very common in kebatinan circles: as unity, the Great Life, immanent in the universe. God is utterly unknowable, but simultaneously man's inner guidance, in other words both far and near. This description can be characterised as a combination of transcendence and immanence, one of the main features of panentheism.

The mystical movements (aliran kebatinan) are firmly rooted in Javanese culture. It certainly is no easy task to present an overall picture of Javanese culture. Clifford Geertz, a well-known authority on the subject, expresses the diversified cultural situation on Java in the following way:

Java-which has been civilised longer than England; which over a period of more than fifteen hundred years has seen Indians, Arabs, Chinese, Portuguese, and Dutch come and go; and which has today one of the world's densest populations, highest development of the arts, and most intensive agricultures-is not easily characterised under a single label or easily pictured in terms of a dominant theme.

GEERTZ 1960: 7

In a chapter like this we will have to limit ourselves to some of the main elements of Javanese religion, especially the themes as presented above: God and creation, the concept of man, and the return to original unity.

The Indonesian anthropologist K.P. H. Koentjaraningrat distinguishes between Agami Jawi ('Javanese Religion') and Agami Islam Santri ('Islam of the Religious People'). "The Agami Jawi manifestation of Islam," according to Koentjaraningrat, "represents an extensive complex of mystically inclined Hindu-Buddhistic beliefs and concepts, syncretistically integrated in an 
Islamic frame of reference" (Koentjaraningrat 1985: 317 ). We will now turn to a few aspects of this worldview called 'Javanese Religion'.

From a cosmological point of view, life on earth is regarded as part of an all-encompassing unity. This unity (yang Suksma) is also called 'life' (urip), since all existence emanates from and will eventually return to this principle. Existence is hierarchical, extending from condensed matter to more subtle levels that are closer to the origin. Man is somewhere in the middle of this great chain of being. With his outer manifestation (lahir) man belongs to the world and its material aspects; the inner nature of man (batin), on the other hand, has connections upwards in the hierarchy. With the aid of his 'intuitive inner feeling' (rasa), man has access to knowledge and experiences inaccessible to those who are bound to the outer, material manifestation of the unity of existence (Mulder 1992b: $5 \mathrm{ff}$ ). Considering this premise, it is easier to understand the attitude of the Javanese towards the Koran, the Bible, or a formalised, institutionalised view of God. There is no need for a 'mediator' as God is immanent in the human heart, God is Life of which every human being is a part (Mulder 1992b: 8).

The Javanese concept of God is non-personal, immanent in all creation. There are, however, also more personal features in the Javanese view of God, features that can be summarised in the following way:

God is the totality of nature, manifested as a small divine being, so tiny that it can enter any human being's heart at any moment, yet he is in reality as wide as the oceans, as endless as space, and he is manifested in the colours which make up and symbolize everything that exists on earth.

KOENTJARANINGRAT 1985:327. See also ZOETMULDER 1935 and MULDER 1992b: 18

There is hardly any doubt that Subuh is in agreement with the general pattern in Javanese mystical literature: the necessary descent of the One into the many, of unity into plurality, and the equally necessary return to original unity. In this basic pattern is also included the view of man in his unique position in this cosmic chain of being, that is, somewhere in the middle, which gives him a possibility to become aware of his original state. The human is a microcosm, and as such they are the sum total of the universe. This doctrine is not limited to Sunfism and Javanese literature from the renaissance period; it is also fundamental in the Javanese Shaiva interpretation of Hinduism.

Subuh's syncretistic presentation of the emanation process is based, I think, on two sources: the Javanese mystical tradition, and Subuh's own experience. Concerning the latter, this explains why the founder of Subud chooses to connect the original state of Unity to "the first vibration" and to describe the "first 
manifestation" as "Light." Both aspects are intimately related to his own experience, which is now linked to the Subud conceptual apparatus. These concepts, in turn, enable a Subud member to interpret his or her experience of vibration as a direct contact with God.

In addition, it is reasonable to assume that the story of Adam and Eve is influenced by court literature like the Paramajoga and similar texts from the nineteenth century renaissance period. I am referring especially to the Serat Wirid, where it is stated that Adam is created out of the four elements and that God inserted spiritual elements in him (Hadiwijono 1967: 106ff). In order to survive in the world Adam was equipped with senses and a heart and mind, all useful in a world consisting of vegetable, animal, human, and other forces.

As far as the concept of humanity is concerned, the doctrines discussed above comprise the seven forces inside and outside the human, the four types of nafsu, the four bodies of humankind, and the concept of jiwa. The first two doctrines are related to each other in such a way that the four so-called lower forces have their counterparts in the four types of passions. This fourfold division of passions occurs first and foremost in Șūfism, which in turn influenced renaissance mystical literature.

Finally, the thoughts pertaining to humanity's return to original unity are also firmly rooted in Șūfi sources. Subuh repeats again and again that the true servant of God should cultivate the following qualities: complete surrender, patience (sabra, Arab. șabr), trust in God (tawakal, Arab. tawakkul), and sincerity (ikhlas, Arab. ikhlās). These concepts belong, of course, to classical Șūfism. In her general description of the Sunfi spiritual path Annemarie Schimmel depicts ikhlas as "absolute sincerity," as a giving up of "selfish thoughts in the service of God." Sincerity is a prerequisite before entering the mystical path proper, one of the stages of which is tawakal, 'trust in God'. A total trust in God implies self-surrender to Him, amounting finally in nothing less than union with God (Schimmel 1975: 108, 117ff).

Another important station on this path is patience, sabar. "Perfect patience," Schimmel writes, "is to accept whatever comes from God, even the hardest blow of fate." Șüfi mystics in all times and places never tired of inventing new parables for this station. In the words of Schimmel:

Only through patience does the fruit become sweet; only through patience can the seed survive the long winter and develop into grain, which, in turn, brings strength to the people, who patiently wait for it to be turned into flour and bread.

SCHIMMEL 1975: 124 
There is a general consensus among Șūfi authors on these issues and that they are in line with the thinking of Muhammad Subuh Sumohadiwidjojo. In conclusion, then, the basic concepts of Subud can be regarded as doctrinal fragments originating predominantly from Hindu inspired and Șūi mystical sources, as elaborated during the Javanese renaissance period.

Subud is amongst other Indonesian "thriving sects" such as Pangestu and Sumarah that draw on Javanese mysticism (Mulder 2005: 28) but Subud considers itself not so much a religion as an organisation centred on the spiritual techniques of latihan as revealed by Muhammad Subuh Sumohadiwidjojo (Subud 2013). This chapter started by briefly detailing the life of Sumohadiwidjojo, fondly known as Bapak, and his founding of Subud after experiencing mystical revelations. Drawing on the primary data generated by his many talks and autobiographical writings over the years, the basic concepts of Subud were outlined, including the concepts of God, creation, humanity, and returning to the state of original unity. The essential spiritual exercise of Subud, latihan kejiwaan, was elaborated upon as a means of experiencing the divine and knowing the self. Finally, although the analysis presented in this chapter is not exhaustive, it can nevertheless be stated that the doctrinal profile of Subud is primarily derived from the Javanese interpretation of Islamic mysticism and to a lesser degree from Hindu-Javanese systems of thought. Thus, Subud represents an Indonesian interpretation of Șüfism in a comparatively new revelatory tradition that exists today on a global scale.

\section{References}

Hadiwijono, H. 1967. Man in the PresentJavanese Mysticism. Baarn: Bosch \& Keunig N.v. Koentjaraningrat, K.P.H. 1985. "Javanese Terms for God and Supernatural Beings and the Idea of Power." In A. Ibrahim, S. Siddique, and Y. Hussain eds, Readings on Islam in Southeast Asia. Singapore: Institute of Southeast Asian Studies, 286-292.

Longcroft, H. 199o. Subud is a Way of Life. Subud Publications International Ltd.

Longcroft, H. 1993. History of Subud. Volume I: The Coming of Subud (1901-1959), Book I: The Beginning in Indonesia. Houston: Al-Baz Publishing, Inc.

McKingley, L. ed. 1992. Adam and His Children. A Brief History of Human Life. Excerpts from Talks by Muhammad Subuh Sumohadiwidjojo. Sydney: Starlight Press. 
Mulder, N. 1978. Mysticism and Everyday Life in Contemporary Java. Cultural Persistance and Change. Singapore: Singapore University Press.

Mulder, N. 1992a. Inside Southeast Asia. Thai, Javanese and Filipino Interpretations of Everyday Life. Bangkok: Editions Duang Kamol.

Mulder, N. 1992b. Individual and Society in Java. A Cultural Analysis. Yogyakarta: Gadjah Mada University Press.

Mulder, N. 2005. Mysticism in Java: Ideology in Indonesia. Yogyakarta: Kanisius.

Needleman, J. 1970. The New Religions. New York: Doubleday \& Company, Inc.

Rieu, D.C.H. ed. 1983. A Life Within a Life. An Introduction to Subud. Talks by Bapak Muhammad Subuh Sumohadiwidjojo. Tunbridge Wells: Humanus.

Schimmel, A. 1975. Mystical Dimensions of Islam. Chapel Hill: The University of North Carolina Press.

Sitompul, P.P. 1974. Susila Budhi Dharma. Subud-International Mystic Movement of Indonesia. Dissertation, Claremont Graduate School.

Subud. 2013. "The Spiritual Practice of Subud." At http://www.subud.com/spiritual .html. Accessed 15/07/202O.

Sumohadiwidjojo, M. 1965. Subud in the World. Ten talks given by Bapak Muhammad Subuh Sumohadiwidjojo at the Second World Congress of the Subud Brotherhood, held at Briarcliff College, New York State, USA, July 1963. Coventry: Subud International Services.

Sumohadiwidjojo, M.1969. The Growth of Subud. Ten talks from the Third International Subud Congress, Tokyo, 1967; and three talks from the Fourth National Subud Congress of Indonesia, 1967. London: Subud Publications International.

Sumohadiwidjojo, M. 1973. Cilandak 71. The Fourth Subud World Congress. Fifteen talks by Bapak Muhammad Subuh. Wiltshire: Subud Publications International.

Sumohadiwidjojo, M. 1976. The Way Ahead. Nine Talks by Muhammad Subuh Sumohadiwidjojo at the Fifth Subud World Congress, Wolfsburg, June 1975. Berks: Subud Publications International.

Sumohadiwidjojo, M. 1979. Bapak's Four Talks for Ramadan 1978 and the Idulfitri Talk. Oxfordshire: Subud Publications International Ltd.

Sumohadiwidjojo, M. 1981. New Directions / 2. Four Talks by Bapak. London: Subud Publications International Ltd.

Sumohadiwidjojo, M. 1981a. All of Mankind. Seventeen Talks by Bapak Muhammad Subuh Sumohadiwidjojo from the 1981 World Tour. Sussex: Subud Publications International Ltd.

Sumohadiwidjojo, M. 1983a. This Is What I Have Been Hoping For. Kent: Subud Publications International Ltd.

Sumohadiwidjojo, M. 1983b. Make your life come good. N.p.: Subud Publications International Ltd. 
Sumohadiwidjojo, M. 1984a. Out into the world. Talks given by Muhammad Subuh Sumohadiwidjojo at the Seventh Subud World Congress held at Anúgraha, August 1983. Kent: Subud Publications International Ltd.

Sumohadiwidjojo, M. 1984b [1961]. Subud and the Active Life. Talks given at the Subud International Congress, 1959. Rickmansworth: Subud Publications International Ltd.

Sumohadiwidjojo, M. 1986. Bapak's Talks, No 2. Tunbridge Wells: Subud Publications International Ltd.

Sumohadiwidjojo, M. 1988a. Bapak's Talks, No 5. Golden Cross: Subud Publications International Ltd.

Sumohadiwidjojo, M. 1988b. Bapak's Talks, No 6. Golden Cross: Subud Publications International Ltd.

Sumohadiwidjojo, M. 1989. Bapak's Talks, No 7. Golden Cross: Subud Publications International Ltd.

Sumohadiwidjojo, M. 199oa. Autobiography, translated by Raymond Lee. Sussex: Subud Publications International Ltd.

Sumohadiwidjojo, M. 199ob. Bapak's Talks, No 9. Golden Cross: Subud Publications International Ltd.

Sumohadiwidjojo, M. 199oc [1957]. Susila Budhi Dharma. Indonesia: Subud Indonesia Publication.

Sumohadiwidjojo, M. 1991. Bapak's Talks, No 11. Golden Cross: Subud Publications International Ltd.

Sumohadiwidjojo, M. 1992. Bapak's Talks, No 12. Golden Cross: Subud Publications International Ltd.

Sumohadiwidjojo, M. 1993. Bapak's Talks. Volume 1, June 1957-June 1958. Wiltshire: Subud Publications International Ltd.

Vittachi, V. 1963. A Reporter in Subud. New York: Dharma Book Company, Inc.

Vittachi, V. 1988. A Memoir of Subud. Bouquets for Bapak. Hailsham, East Sussex: Subud Publications International Ltd.

Zoetmulder, P.J. 1935. Pantheisme en monisme in de Javaansche Soeloek-litteratuur. Nijmegen: J.J. Berkhout. 